\title{
Population genetics of Bursatella leachii (De Blainville, 1817) and implications for the origin of the Mediterranean population
}

\author{
Enrico Bazzicalupo ${ }^{1 *}$, Fabio Crocetta ${ }^{2}$, Ka'ala Estores-Pacheco ${ }^{1}$, Haleh Golestani ${ }^{1}$, Hocein Bazairi ${ }^{3}$, \\ Salvatore Giacobbe ${ }^{4}$, Andrej Jaklin", Dimitris Poursanidis ${ }^{6}$, B. K. Sneha Chandran${ }^{7}$ Juan Lucas Cervera ${ }^{8,9}$ \\ and Ángel Valdés ${ }^{1 *}$
}

\begin{abstract}
The sea hare Bursatella leachii (de Blainville 1817) (Mollusca: Gastropoda: Heterobranchia: Aplysiidae) is a pantropical sea slug that has colonized the Mediterranean Sea in modern times. Because the initial records in the non-native range started in the Eastern Mediterranean, and its pattern of spread was relatively consistent with those observed in well-known Lessepsian invaders, B. leachii is commonly considered to be a migrant from the Red Sea. In this study, we investigate for the first time the origin of the Mediterranean populations of B. leachii inferring their population structure and assessing relatedness levels of different regional populations. Sequence data from the cytochrome oxidase I were used to conduct population genetic analyses on this species, particularly by investigating the genetic structure of Atlantic, Mediterranean, and Indo-Pacific populations. Our results confirm that B. leachii is a truly pantropical species which displays geographic structure among major ocean basins. More importantly, sequenced Mediterranean and Atlantic animals share similar or identical haplotypes, which are distinct in at least 5 substitutions from haplotypes recovered from Indo-Pacific specimens. The results suggest that the Mediterranean population of B. leachii here examined probably have an Atlantic origin, and for the first time casts doubts on the assumed primary pathway of migration into the Mediterranean Sea.
\end{abstract}

Keywords: Mollusca, Heterobranchia, Mediterranean Sea, Alien species, Population genetics

\section{Background}

The Mediterranean Sea constitutes a particularly interesting system to study marine biological invasions. Because it is a relatively closed basin, connected to two markedly distinct biogeographic regions (the Atlantic Ocean and the Red Sea), the Mediterranean is susceptible to invasion by organisms adapted to different environmental conditions and having very different evolutionary histories. Marine alien species can potentially enter and settle in the Mediterranean through its three aquatic open access points (the Gibraltar Strait, the Suez Canal, and the Bosporus) by a wide range of

\footnotetext{
*Correspondence: enricobazzical@gmail.com; aavaldes@cpp.edu ${ }^{1}$ Department of Biological Sciences, California State Polytechnic University, 3801 West Temple Avenue, Pomona, CA 91768, USA Full list of author information is available at the end of the article
}

different vectors [1]. Some species have been introduced by direct human activities such as aquarium trade, shipping, or aquaculture, which constitute the most common vectors of introduction of alien species in marine environments worldwide [2]. Others, the so called Lessepsian or Eritrean migrants [3], have arrived into the Mediterranean by "natural" dispersal during their larval stage from the Red Sea [1]. This is the most common pathway for Mediterranean invasions, and it is likely to become more prevalent in the future because of the recent expansion of the Suez Canal [3]. Moreover, the "tropicalization" of the Mediterranean [4] has resulted in species poleward distributional shifts, and has favored the arrival of tropical species to temperate regions [5]. Also, these shifts in environmental and ecological conditions have facilitated the successful establishment of species introduced by direct human 
activities in the Mediterranean [6]. To add to this complexity, the weakening of natural barriers for dispersal from the Atlantic Ocean into the Mediterranean, such as the Canary Current [7] and the Almería-Oran Front [8], caused by climate change, have facilitated the recent migration of tropical Atlantic species into the Mediterranean [9].

The ragged sea hare Bursatella leachii (de Blainville, 1817) (Gastropoda: Heterobranchia: Aplysiidae) is a benthic detritivore typically found grazing on the surface layers of muddy and sandy bottoms of protected bays and estuaries; it is distributed worldwide in tropical and warm temperate waters [10-15] and present in the Mediterranean as an established alien species [16, 17]. Because apparently B. leachii colonized the Mediterranean starting in the mid-20th century in an eastto-west direction (Fig. 1), almost all authors working on the Mediterranean biota have hypothesized a Red Sea origin of the local populations, categorizing $B$. leachii as a Lessepsian migrant [e.g. 17-21, among recent reviews]. However, molecular studies have never been used to more accurately determine the origin of these populations. In this study, we used a population genetics approach through mtDNA sequence data to infer the population structure of $B$. leachii for the first time across its entire range and to determine the genetic affinities of the Mediterranean population, therefore testing the origin of this invasion event.

\section{Methods}

Specimens

A total of 33 individuals from various localities across the global range of B. leachii were studied (Fig. 2). The samples were preserved in 70-90\% ethanol; some consisted of full specimens, while others were small pieces of tissue cut from either the foot or the mantle of the animal. The specimens were collected in the field, mainly by scuba diving and snorkeling at low tide or obtained from the Cal Poly Pomona Invertebrate Collection (CPIC) and the Invertebrate Zoology collection of the California Academy of Sciences (CASIZ). A full list of specimens with locality and collection date is available in Table 1 . The list also comprises the GenBank accession numbers for all of the sequences as well as those obtained from GenBank used in the study.

\section{DNA extraction, amplification, sequencing}

A small piece cut from the tissue sample or from the foot or mantle of the full specimen was fragmented using sterile forceps and razor blades. DNA of more recently collected specimens was extracted using the Hot Chelex ${ }^{\circledR}$ extraction method. For older specimens, the DNeasy Blood and Tissue Kit (Qiagen) was used. The Hot Chelex ${ }^{\circledR}$ extraction was conducted as follows. After maceration, the tissue was transferred in $1 \mathrm{~mL}$ of $1 \mathrm{X}$ TE Buffer, contained in a $1.7 \mathrm{~mL}$ microcentrifuge tube. To allow the tissue to rehydrate and the cells to lyse, the tube was then

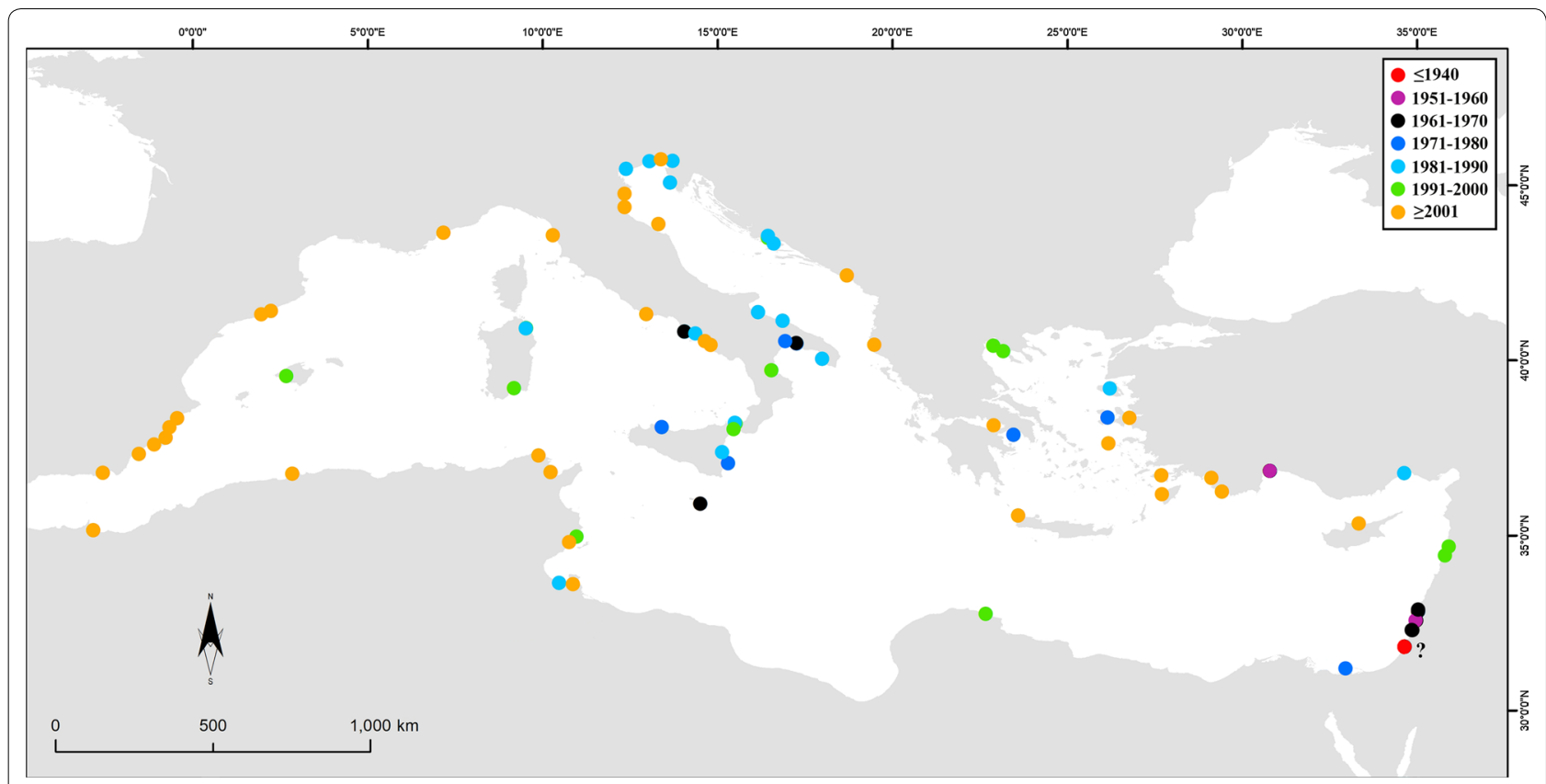

Fig. 1 Records of Bursatella leachii in the Mediterranean Sea, adapted from [17, 41]. Dots indicate the location of each sighting, reference list in Selfati et al. [17]. The decades in which the first sighting occurred for each location are coded by color (black: 1950's and 60's; dark blue: 1970's; light blue: 1980's; green: 1990's; orange: 2000 to present) 


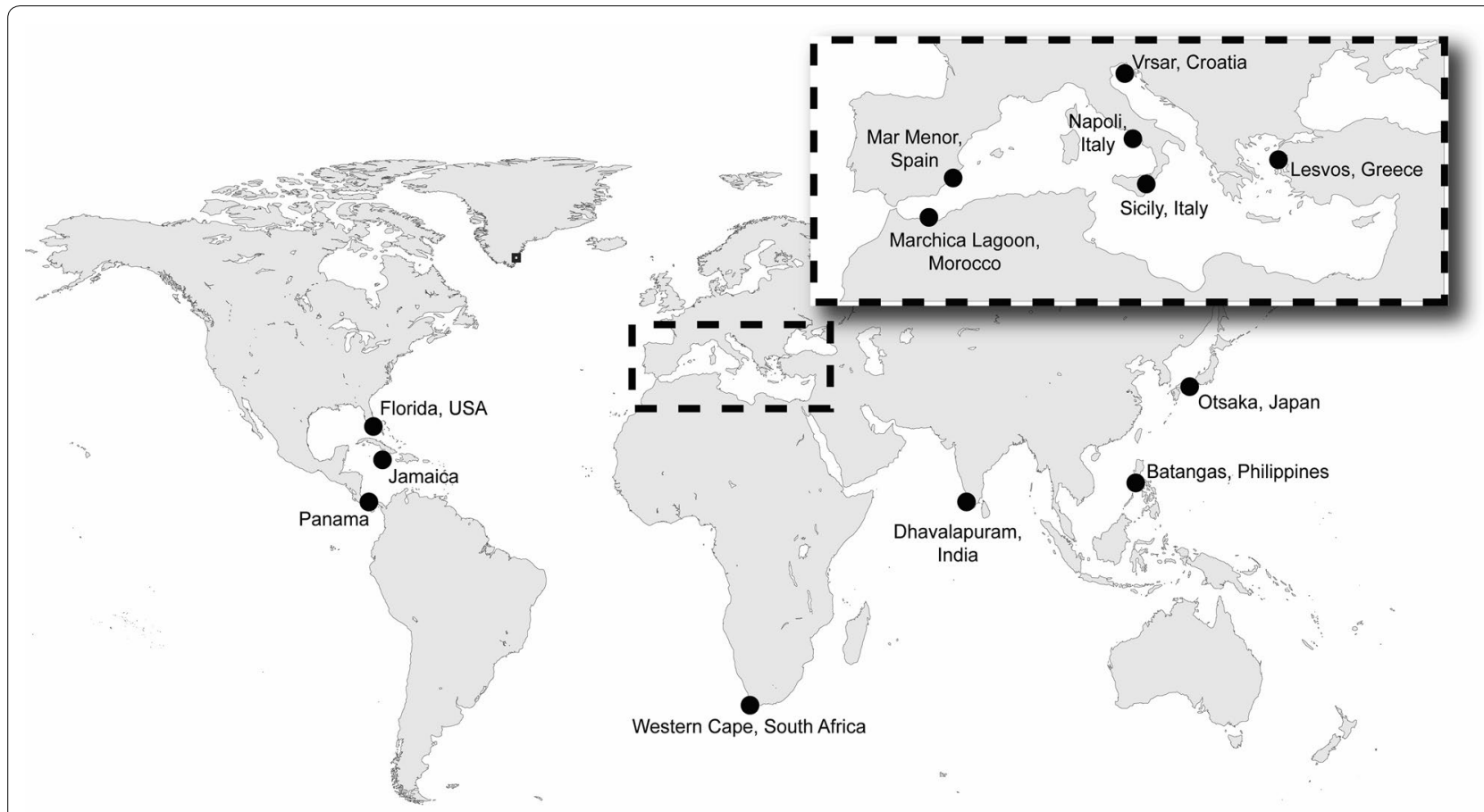

Fig. 2 Map showing localities of specimens sequenced for this study. Multiple specimens from the same locality are merged into a single point

placed on a rotating block for at least $20 \mathrm{~min}$. After this time, the tube was vortexed for $5 \mathrm{~s}$ and then centrifuged for $3 \mathrm{~min}$ at 21,000g. Careful not to disturb the tissue pellet, $975 \mu \mathrm{L}$ of $1 \mathrm{X}$ TE Buffer were removed from the tube, and $175 \mu \mathrm{L}$ of $10 \% \mathrm{Chelex}^{\circledR}$ solution were then added to the tube. After being vortexed, the tube was put in a $56^{\circ} \mathrm{C}$ hot water bath for at least $20 \mathrm{~min}$. After $5 \mathrm{~s}$ of vortexing, the tube was then put in a $100{ }^{\circ} \mathrm{C}$ heat block for exactly $8 \mathrm{~min}$. Finally, the tube was vortexed and centrifuged for $3 \mathrm{~min}$ at $21,000 \times g$. The supernatant resulting from the centrifugation, was then used as a template for amplification through Polymerase Chain Reaction (PCR). DNeasy extraction was conducted following the manufacturers' protocol for tissue samples.

A portion of the cytochrome c oxidase 1 (COI) mitochondrial gene was amplified by PCR. For the amplification of COI, both the universal primers (LCOI490 5' - G GT CAA CAA ATC ATA AAG ATA T TG G-3', HCO2198 5'-TAAACTTCAGGGTGACCAAAAAAT CA-3') identified by Folmer et al. [22], and specific primers designed for B. leachii (Forward 5'-GGGATGTGA TGTGGTCTAGTAGGAAC- $3^{\prime}$, Reverse $5^{\prime}$-ATAGGA TCTCCTCCTCCCGCAGGATC-3'), were used in this study. Each reaction tube contained a total of $50 \mu \mathrm{L}$ of reaction mixture, which included: $0.25 \mu \mathrm{L}$ of $5 \mathrm{u} /$ $\mu \mathrm{L}$ taq polymerase, $5.00 \mu \mathrm{L}$ of $10 \times$ PCR buffer, $5.00 \mu \mathrm{L}$ of $25 \mathrm{mM} \mathrm{MgCl}_{2}, 1.00 \mu \mathrm{L}$ of $40 \mathrm{mM}$ dNTPs, $1.00 \mu \mathrm{L}$ of each $10 \mathrm{mM}$ primer, $34.75 \mu \mathrm{L}$ of $\mathrm{H}_{2} \mathrm{O}$ and $2.00 \mu \mathrm{L}$ of template DNA. The thermocycler was set as follows: $3 \mathrm{~min}$ at $95^{\circ} \mathrm{C}$ for an initial denaturation of the DNA; 35 cycles of denaturation at $94{ }^{\circ} \mathrm{C}$ for $45 \mathrm{~s}$, annealing at $45^{\circ} \mathrm{C}$ for $45 \mathrm{~s}$ and elongation at $72{ }^{\circ} \mathrm{C}$ for $90 \mathrm{~s}$; a final elongation step of 10 min at $72{ }^{\circ} \mathrm{C}$.

A $10 \%$ agarose gel was prepared and stained with ethidium bromide, and a gel electrophoresis of the PCR products was run, in order to verify the presence of DNA fragments. PCR products that showed appropriate size fragments were then purified using the GeneJET PCR Purification Kit by Thermo Scientific, following the manufacturers' protocol. Concentrations of the purified DNA fragments were then checked using a NanoDrop 1000 spectrophotometer (Thermo Scientific) and sent to the Source Biosciences (San Diego, CA) company, which performed Sanger sequencing of the fragments. Assemblage and editing of the sequences was done with the software GENEIOUS PRO 4.7.4 [Biomatters Ltd., 23]. Consensus sequences were aligned and concatenated for the following analyses using the same software.

\section{Population genetics}

Population genetics analyses were conducted using partial sequences of the cytochrome c oxidase subunit I (COI) mitochondrial gene. In order to visualize and interpret genetic data at a population-scale level, a haplotype 
Table 1 Specimens sequenced, including collection code, isolate number, collection locality, region and date and GenBank accession numbers

\begin{tabular}{|c|c|c|c|c|c|c|}
\hline Taxon & Code & Isolate & Date & Locality & Region & GenBank Accession \# \\
\hline Bursatella leachii & $\#$ & EN-201 & 2017 & Croatia: Vrsar & Adriatic Sea & MH837984 \\
\hline Bursatella leachii & $\#$ & EN-202 & 2017 & Croatia: Vrsar & Adriatic Sea & MH837983 \\
\hline Bursatella leachii & $\#$ & EN-203 & 2017 & Croatia: Vrsar & Adriatic Sea & MH837978 \\
\hline Bursatella leachii & GenBank & BURIC1 & - & Spain: Mar Menor & Western Mediterranean & KJ187403 \\
\hline Bursatella leachii & $\#$ & EN-205 & 2008 & Italy: Gulf of Naples & Western Mediterranean & MH837982 \\
\hline Bursatella leachii & $\#$ & EN-213 & - & Italy: Sicily & Ionian Sea & MH837985 \\
\hline Bursatella leachii & $\#$ & HG-88 & - & Italy: Sicily & Ionian Sea & MH837993 \\
\hline Bursatella leachii & $\#$ & KP-1H3 & 2016 & Morocco: Marchica Lagoon & Alboran Sea & MH837979 \\
\hline Bursatella leachii & CPIC-02034 & KP-58 & 2016 & Morocco: Marchica Lagoon & Alboran Sea & MH837980 \\
\hline Bursatella leachii & CPIC-02036 & KP-60 & 2016 & Morocco: Marchica Lagoon & Alboran Sea & MH837981 \\
\hline Bursatella leachii & CPIC-02031 & KP-55 & 2016 & Morocco: Marchica Lagoon & Alboran Sea & MH837971 \\
\hline Bursatella leachii & CPIC-02023 & KP-25 & 2016 & Morocco: Marchica Lagoon & Alboran Sea & MH837973 \\
\hline Bursatella leachii & CPIC-02035 & KP-59 & 2016 & Morocco: Marchica Lagoon & Alboran Sea & MH837975 \\
\hline Bursatella leachii & CPIC-02025 & KP-27 & 2016 & Morocco: Marchica Lagoon & Alboran Sea & MH837976 \\
\hline Bursatella leachii & $\#$ & HG-121 & 2017 & Greece: Lesvos island & Aegean Sea & MH837987 \\
\hline Bursatella leachii & $\#$ & HG-123 & 2017 & Greece: Lesvos island & Aegean Sea & MH837986 \\
\hline Bursatella leachii & $\#$ & HG-124 & 2017 & Greece: Lesvos island & Aegean Sea & MH837988 \\
\hline Bursatella leachii & $\#$ & HG-125 & 2017 & Greece: Lesvos island & Aegean Sea & MH837989 \\
\hline Bursatella leachii & $\#$ & HG-126 & 2017 & Greece: Lesvos island & Aegean Sea & MH837991 \\
\hline Bursatella leachii & $\#$ & HG-127 & 2017 & Greece: Lesvos island & Aegean Sea & MH837990 \\
\hline Bursatella leachii & CPIC-00647 & JS-209 & 2011 & Jamaica: Iberostar Rose Hall Beach & Atlantic & MH837970 \\
\hline Bursatella leachii & CPIC-01430 & EN-016 & 2015 & Panama: Bocas del Toro & Atlantic & MH837974 \\
\hline Bursatella leachii & CPIC-00482a & GB-03 & 2006 & Panama: Bocas del Toro & Atlantic & MH837977 \\
\hline Bursatella leachii & CPIC-00482b & GB-04 & 2006 & Panama: Bocas del Toro & Atlantic & MH837972 \\
\hline Bursatella leachii & GenBank & GB-05 & - & USA: Florida & Atlantic & AF156146 \\
\hline Bursatella leachii & CASIZ-176327 & EN-018 & 2008 & South Africa: Western Cape Province & South Africa & MH837965 \\
\hline Bursatella leachii & $\#$ & $\mathrm{EN}-115$ & 2013 & Japan: Sakai city: Otsaka & Indo-Pacific & MH837968 \\
\hline Bursatella leachii & $\#$ & EN-113 & 2013 & Japan: Sakai city: Otsaka & Indo-Pacific & MH837967 \\
\hline Bursatella leachii & $\#$ & EN-114 & 2013 & Japan: Sakai city: Otsaka & Indo-Pacific & MH837966 \\
\hline Bursatella leachii & CASIZ-202048b & EN-105 & 2014 & Philippines: Luzon Island: Batangas Province & Indo-Pacific & MH837969 \\
\hline Bursatella leachii & $\#$ & HG-112 & - & India: Dhalavapuram & Indo-Pacific & MH837994 \\
\hline Bursatella leachii & $\#$ & HG-113 & - & India: Dhalavapuram & Indo-Pacific & MH837995 \\
\hline
\end{tabular}

CASIZ California Academy of Sciences, CPIC Cal Poly Invertebrate Collection

Missing data $="{ }^{\prime \prime}$

Tissue sample only $=" \# "$

network was constructed using the TCS method [24] implemented in the software PopART (http://popar t.otago.ac.nz). In order to assess the relatedness level of the different haplotypes, a matrix of pairwise genetic distances was constructed using the software MEGA 7.0.26 [25], using the Kimura 2-parameter model [26]. Distance values were plotted in a histogram.

\section{Results}

The haplotype network analysis reveals there is geographic structure in B. leachii populations (Fig. 3), with two distinct haplogroups separated by four mutational changes. One includes haplotypes from the West Pacific, India, Japan, and South Africa. The other haplogroup includes samples from the Caribbean and the Mediterranean. In the Atlanto-Mediterranean haplogroup, the most common haplotype is shared among Atlantic and Mediterranean specimens. Most of other Mediterranean and Caribbean haplotypes only differ from that common haplotype by one nucleotide substitution, and the most distant ones differ by three mutational changes.

A histogram of the pairwise genetic distances is shown in Fig. 4. Most of the haplotypes are either identical to one another or very similar, with low genetic distance 


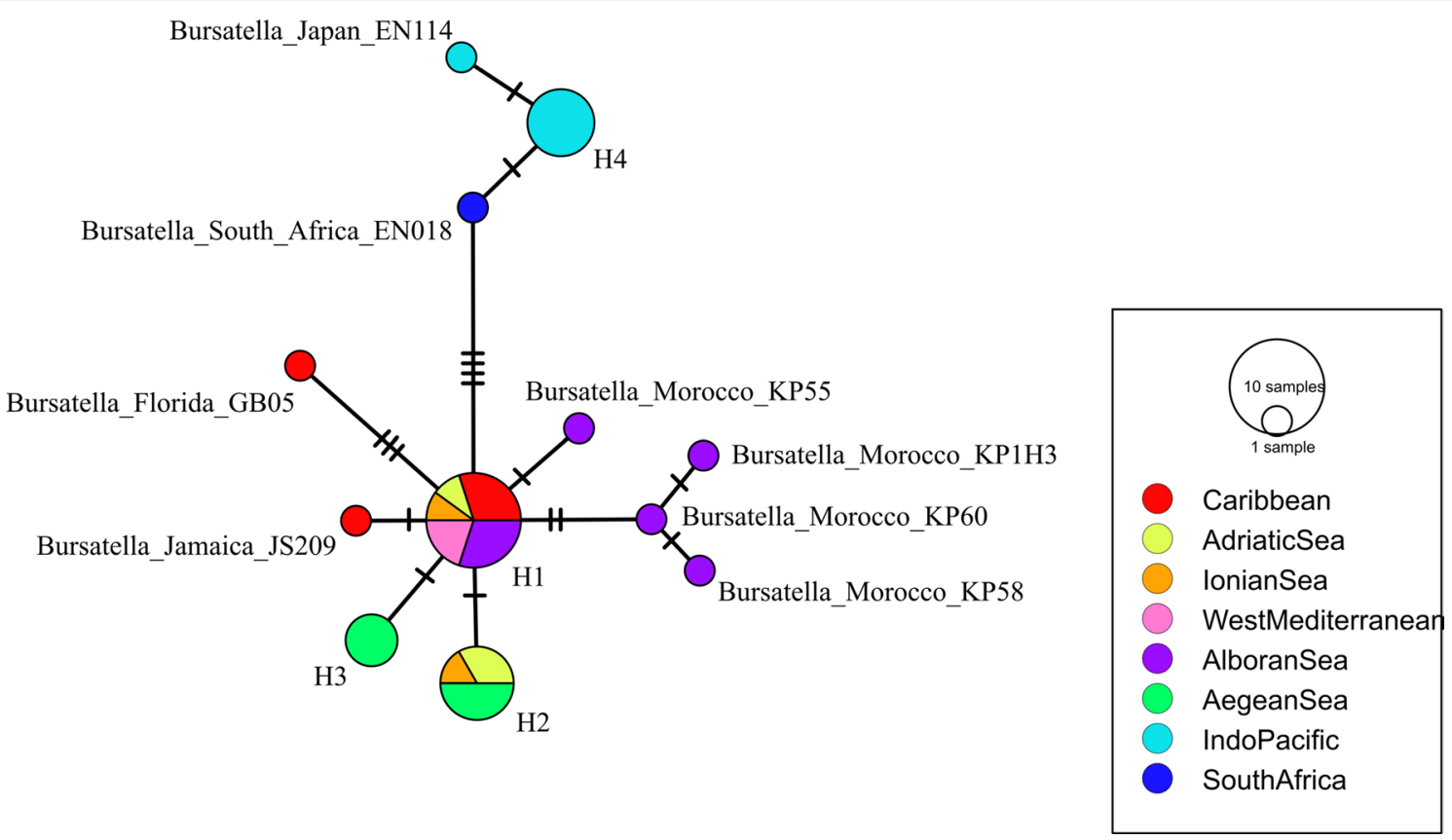

Fig. 3 COI haplotype network produced with the TCS method in PopART. Geographic region in which each haplotype was found is coded by color. The relative size of the circles is proportional to the number of sequences of that same haplotype. For haplotypes found in only one specimen, the isolate and location is indicated. The groups of specimens sharing the same haplotype are as follows: H1 (isolates: GB03, GB04, EN016, EN203, EN205, KP25, KP27, KP59, BURIC1, HG88), H2 (isolates: EN201, EN202, EN213, HG124, HG125, HG127), H3 (isolates: HG121, HG123, HG126) and H4 (isolates: EN105, EN113, EN115, HG112, HG113)

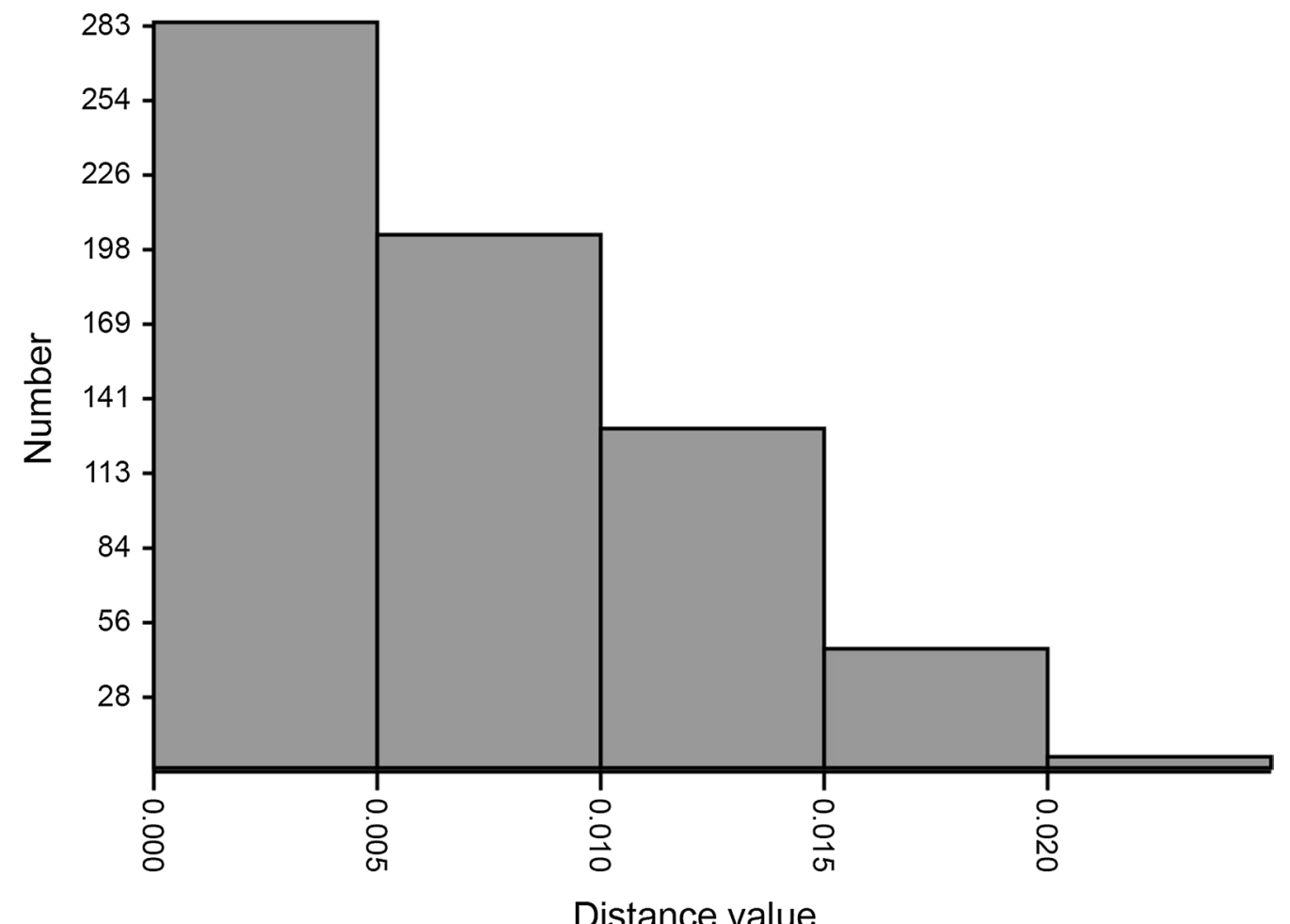

Fig. 4 Histogram of pairwise genetic distances among COI haplotypes calculated with the Kimura-2 model in MEGA 
among them. Higher genetic distances among haplotypes are less common. There appears to be a linear inverse relationship between distance values and their frequency, without gaps in intermediate distances.

\section{Discussion}

The main results from the present paper revealed that although Pacific and Atlantic populations of B. leachii are genetically distinct, the divergence between populations from these two geographic regions is relatively small ( 5 substitutions), suggesting $B$. leachii is likely to be a true pantropical species, experiencing relatively recent gene flow across ocean basins. This is supported by the results of the genetic distance calculations (Fig. 4), which show that no barcoding gap is present between the frequency of higher distances (intraspecific) and lower distances (interspecific). The finding of a single species contrasts with the majority of similar examples studied to date. In fact, most pantropical species of sea slug have not survived the advent of molecular systematics [see 27-32], with the sole exception of the pelagic aeolid nudibranch Glaucus atlanticus (Forster, 1777). A possible difference between B. leachii and G. atlanticus with the other species, which could explain their unique range, is that both species also occur in cold and temperate waters in South Africa, and this region could serve as a gateway that allows the maintenance of gene flow between the South Atlantic and the Indian Ocean [33]. Studies on the reproduction and population dynamics of $B$. leachii conducted by Paige [34] and Clarke [35] may provide additional support for such a broad range and dispersal ability. The planktonic larvae of $B$. leachii can survive for more than 3 months after hatching, and adults have relatively short life cycles, reaching maturity in only $2-3$ months [34]. At the same time, when compared to other sea hares, $B$. leachii is able to reach relatively large population sizes even when lacking access to optimal food sources [35], a life history trait advantageous for a species colonizing a new territory [36].

Another result obtained from this study, is that no shared haplotypes between the Indo-Pacific region and the Mediterranean were found, despite of a relatively large Mediterranean sample size and sampling effort covering both the eastern and western Mediterranean. In addition to the membership to the same haplogroup, the existence of identical haplotypes strongly suggest a shared demographic history between populations of $B$. leachii of the Atlantic and Mediterranean regions. On the contrary, all Indo-Pacific haplotypes sequenced for this study, including specimens from the Indian Ocean and South Africa, are genetically distinct by at least 5 substitutions from all of the Atlantic and Mediterranean haplotypes. Therefore, although most authors have considered the Mediterranean populations of $B$. leachii to have an Indo-Pacific origin (see above), the data presented here suggest otherwise, that at least a part of the B. leachii populations in the Mediterranean Sea have migrated from the Atlantic Ocean. One important caveat is that for this study we had no access to specimens from the Red Sea, which prevent us from rejecting with certainty a Lessepsian origin. However, a Red Sea origin hypothesis would require the existence of Red Sea populations genetically similar to those present in the Caribbean and Mediterranean and different from those in other IndoPacific regions studied herein, including other Indian Ocean populations. If such population were found, it would suggest an anti-Lessepsian migration into the Red Sea, rather than a Red Sea origin of B. leachii.

The data here presented opens the possibility of an alternative pattern of colonization of the Mediterranean, but the mechanisms responsible for the invasion remain unclear. One hypothesis is that the migration into the Mediterranean could be human-mediated. Transport by ship ballast water has been shown to be one of the most common vectors by which alien marine species can disperse into new habitats [2]. However, B. leachii has planktotrophic larvae, which typically encounter suboptimal growth conditions while traveling in ballast water tanks [37], reducing their ability to survive long journeys. Moreover, the spatial patterns of dispersal shown during the colonization of the Mediterranean are inconsistent with a ballast water mediated introduction event. For example, there is no clear link between the first sightings and proximity to the main Mediterranean harbors, where ballast water should had been discharged. An alternative hypothesis is that the colonization of Mediterranean could be the result of non-human mediated dispersal of $B$. leachii through the Gibraltar Strait. Although the Mediterranean Sea has been connected with the Atlantic Ocean through the Gibraltar Strait for more than 5 million years [8], recent oceanographic changes caused by global warming have altered the permeability of barriers to dispersal. For example, the weakening of the cold Canary Current and Saharan upwelling [7], which historically prevented the dispersal of tropical West African species into the Mediterranean, might have resulted in milder winters throughout the last century [38]. This should have facilitated the spread of species, which maintain populations in West Africa, like B. leachii. Nevertheless, the east to west direction of colonization observed in B. leachii appears to contradict this hypothesis. At least two explanations can be advanced to justify this counter-intuitive pattern. A similar pattern has been locally observed in another tropical sea hare, Aplysia dactylomela (Rang 1828). Valdés et al. [39] suggested that larvae of $A$. dactylomela, upon entering in the Mediterranean, 
were transported by the Algerian current directly into the Central and Eastern Mediterranean, where the first records were registered, therefore bypassing the Western Mediterranean. The observed pattern of Mediterranean colonization of $B$. leachii is not identical to the that observed for A. dactylomela, but it is comparable, and a similar case could be made to explain the first reports of $B$. leachii in the Eastern Mediterranean. Another possible explanation is that $B$. leachii, after entering the Western Mediterranean from the Atlantic, could have migrated towards the Eastern Mediterranean by stepping-stone dispersal. Permanent populations might not have established on the way to the Eastern Mediterranean most probably because of sub-optimal temperature conditions for survival, hence no sightings in that area have been registered. More recently, the warming of the Mediterranean has resulted in more favorable conditions for settlement of warm-water species [4, 6]. Differences in winter sea surface temperatures have been hypothesized as creating a division between distributional ranges of cold and warm water biota in the Mediterranean [35]. The February sea surface temperature isotherm of $15^{\circ} \mathrm{C}$, in particular, represents the possible northern limit to the distributional range of different warm water species [40]. With temperatures increasing during the most recent decades [38], these "barriers" have also shifted [40], and B. leachii might have found more suitable conditions for establishment and colonization of the Western Mediterranean (see Fig. 1).

\section{Conclusions}

The results of this study suggest that $B$. leachii is likely to be a true pantropical species, and provide for the first time evidence that at least part of the Mediterranean population of B. leachii has originated in the Atlantic Ocean, contrary to what was previously inferred purely from the sequence of sightings. Different hypotheses regarding the mechanism behind the migration into the Mediterranean were formulated, considering both manmade and natural dispersal possibilities. The uncertainty of $B$. leachii native range and relatively small sample size of the study, limit our ability to test these additional hypotheses.

\footnotetext{
Authors' contributions

EB extracted and amplified DNA of part of the specimens, conducted sequence alignment and analysis (haplotype network), prepared Figs. 1, 3 and 4 , and was a major contributor in writing the manuscript. FC co-supervised the project, helped prepare Fig. 2, and was a major contributor in writing the manuscript. KEP and HG extracted and amplified DNA of part of the specimens. HB, SG, AJ, SC and JLCC contributed to specimen acquisition, and corrected and improved the final manuscript. DP contributed to specimen acquisition, prepared Fig. 2, and corrected and improved the final manuscript. AV supervised the project, contributed to specimen acquisition, conducted sequence alignment and analysis ( $\Phi_{\text {ST }}$ pairwise analysis), and was a major
}

contributor in writing the manuscript. All authors read and approved the final manuscript.

\begin{abstract}
Author details
${ }^{1}$ Department of Biological Sciences, California State Polytechnic University, 3801 West Temple Avenue, Pomona, CA 91768, USA. ${ }^{2}$ Department of Integrative Marine Ecology, Stazione Zoologica Anton Dohrn, Villa Comunale, 80121 Naples, Italy. ${ }^{3}$ BioBio Research Center, Faculty of Sciences, Mohammed V University in Rabat, 4 Avenue Ibn Battouta, B.P. 1014 RP, Rabat, Morocco. ${ }^{4}$ ChiBioFarAm Department, Messina University, Viale Ferdinando Stagno d'Alcontres 31, 98166 S. Agata-Messina, Italy. ${ }^{5}$ Center for Marine Research, Ruđer Bošković Institute, G. Paliaga 5, 52210 Rovinj, Croatia. ${ }^{6}$ Foundation for Research and Technology - Hellas (FORTH), Institute of Applied and Computational Mathematics, N. Plastira 100, Vassilika Vouton, 70013 Heraklion, Greece. ${ }^{7}$ Department of Aquatic Biology and Fisheries, University of Kerala, Thiruvananthapuram, Kerala 695581, India. ${ }^{8}$ Departamento de Biología, Facultad de Ciencias del Mar y Ambientales, Campus de Excelencia Internacional del Mar (CEIMAR), Universidad de Cádiz, Avenida República Saharaui, s/n, Ap.40, 11510 Puerto Real, Cádiz, Spain. ${ }^{9}$ Instituto Universitario de Investigación Marina (INMAR), Campus de Excelencia Internacional del Mar (CEIMAR), Universidad de Cádiz, Av. República Saharaui, s/n, Ap.40, 11510 Puerto Real, Cádiz, Spain.
\end{abstract}

\section{Acknowledgements}

Hessam Ghanimi, Jennifer McCarthy, and Sabrina Medrano (California State Polytechnic University, USA) greatly helped with the laboratory work. Elena Tricarico (University of Florence) helped with the writing of part of the manuscript and supervised EB's work during his Master thesis. Biju Kumar (University of Kerala, India) assisted with the specimens from India. Liz Kools and Terry Gosliner facilitated the loan from the CASIZ. Dr R. Ravinesh greatly assisted during field collection in India. An anonymous reviewer provided precious insight and suggestions that greatly helped to improve the manuscript.

\section{Competing interests \\ The authors declare that they have no competing interests.}

\section{Availability of data and materials}

All sequences analyzed in this study are available in GenBank (https://www. ncbi.nlm.nih.gov/genbank/). Accession number for each sequence can be found in Table 1.

\section{Consent for publication \\ Not applicable.}

Ethics approval and consent to participate Not applicable.

\section{Funding}

The TROPIMUNDO Steering Board provided funding for traveling expenses through the TROPIMUNDO Thesis Grant. The Department of Science and Technology (Government of India) provided funding through the INSPIRE fellowship.

\section{Publisher's Note}

Springer Nature remains neutral with regard to jurisdictional claims in published maps and institutional affiliations.

Received: 18 May 2018 Accepted: 22 November 2018

Published online: 28 November 2018

\section{References}

1. Katsanevakis S, Zenetos A, Belchior C, Cardoso AC. Invading European seas: assessing pathways of introduction of marine aliens. Ocean Coast Manag. 2013;76:64-74.

2. Molnar JL, Gamboa RL, Revenga C, Spalding MD. Assessing the global threat of invasive species to marine biodiversity. Front Ecol Environ. 2008;6(9):485-92. 
3. Galil BS, Boero F, Campbell ML, Carlton JT, Cook E, Fraschetti S, Gollasch S, Hewitt CL, Jelmert A, Macpherson E, Marchini A, McKenzie C, Minchin D, Occhipinti-Ambrogi A, Ojaveer H, Olenin S, Piraino S, Ruiz GM. 'Double trouble': the expansion of the Suez Canal and marine bioinvasions in the Mediterranean Sea. Biol Invasions. 2015;17(4):973-6.

4. Raitsos DE, Beaugrand G, Georgopoulos D, Zenetos A, Pancucci-Papadopoulou AM, Theocharis A, Papathanassiou E. Global climate change amplifies the entry of tropical species into the Eastern Mediterranean Sea. Limnol Oceanogr. 2010;55(4):1478-84.

5. Cheung WW, Lam VW, Sarmiento IL, Kearney K, Watson R, Pauly D. Projecting global marine biodiversity impacts under climate change scenarios. Fish Fish. 2009;10(3):235-51.

6. Bianchi CN, Morri C. Global sea warming and "tropicalization" of the Mediterranean Sea: biogeographic and ecological aspects. Biogeogr I Integr Biogeogr. 2003;24:319-27.

7. Vermeij GJ. The tropical history and future of the Mediterranean biota and the West African enigma. J Biogeogr. 2012;39:31-41.

8. Patarnello T, Volckaert FAMJ, Castilho R. Pillars of Hercules: is the Atlantic Mediterranean transition a phylo-geographical break? Mol Ecol. 2007;16:4426-44.

9. Canning-Clode J, Carlton JT. Refining and expanding global climate change scenarios in the sea: poleward creep complexities, range termini, and setbacks and surges. Divers Distrib. 2017;23(5):463-73.

10. Bebbington A. Bursatella leachi guineensis subsp. nov. (Gastropoda, Opisthobranchia) from Ghana. J Molluscan Stud. 1969;38(4):323-41.

11. Marcus EDBR. On the Anaspidea (Gastropoda: Opisthobranchia) of the warm waters of the western Atlantic. Bull Mar Sci. 1972;22(4):841-74.

12. Bebbington A. Aplysiid species from East Africa with notes on the Indian ocean Aplysiomorpha (Gastropoda: opisthobranchia). Zool J Linn Soc 1974;54(1):63-99.

13. Gosliner TM. Marine Gastropoda collected by the Steamer Albatros from the Philippines in 1908. Rec West Aust Mus Suppl. 2006;69:83-93.

14. Ortea J, Espinosa J, Caballer M, Buske Y. Initial inventory of the sea slugs (Opisthobranchia and Sacoglossa) from the expedition KARUBENTHOS, held in May 2012 in Guadaloupe (Lesser Antilles, Caribbean Sea). Revista de la Academia Canaria de Ciencias. 2012;24(3):153-82.

15. Sethi S, Kokane MR, Otta SK, Sethi G. First record of ragged sea hare Bursatella leachii Blainville, 1817 (Opisthobranchia: Euopisthobranchia: Aplysiidae) in Pulicat Lake, east coast of India. Mar Biodivers Rec. 2015;8:e34.

16. Barash A, Danin Z. Opisthobranchia (Mollusca) from the Mediterranean waters of Israel. Isr J Zool. 1971;20(3):151-200.

17. Selfati M, El Ouamari N, Crocetta F, Mesfioui A, Boissery P, Bazairi H. Closing the circle in the Mediterranean Sea: Bursatella leachii Blainville, 1817 (Mollusca: Gastropoda: Anaspidea) has reached Morocco. Biolnvasions Rec. 2017;6(2):129-34

18. Occhipinti-Ambrogi A, Marchini A, Cantone G, Castelli A, Chimenz C, Cormaci M, Froglia C, Furnari G, Gambi M, Giaccone G, Giangrande A, Gravili C, Mastrototaro F, Mazziotti C, Orsi-Relini L, Piraino S. Alien species along the Italian coasts: an overview. Biol Invasions. 2011;13(1):215-37.

19. Galil BS, Marchini A, Occhipinti-Ambrogi A, Minchin D, Narščius A, Ojaveer $\mathrm{H}$, Olenin S. International arrivals: widespread bioinvasions in European seas. Ethol Ecol Evol. 2014;26:152-71.

20. Gofas S, Luque AA, Templado J, Salas C. A national checklist of marine Mollusca in Spanish waters. Sci Mar. 2017;81 (2):241-54.

21. Crocetta F, Gofas S, Salas C, Tringali LP, Zenetos A. Local ecological knowledge (LEK) versus published literature: a review of non-indigenous Mollusca in Greek marine waters. Aquat Invasions. 2018;13:679-90.

22. Folmer O, Black M, Hoeh W, Lutz R, Vrijenhoek R. DNA primers for amplification of mitochondrial cytochrome c oxidase subunit I from diverse metazoan invertebrates. Mol Mar Biol Biotechnol. 1994;3(5):294-9.

23. Kearse M, Moir R, Wilson A, Stones-Havas S, Cheung M, Sturrock S, Buxton S, Cooper A, Markowitz S, Duran C, Thierer T, Ashton B, Mentjies P, Drummond A. Geneious basic: an integrated and extendable desktop software platform for the organization and analysis of sequence data. Bioinformatics. 2012;28(12):1647-9.
24. Clement M, Snell Q, Walker P, Posada D, Crandall K. TCS: estimating gene genealogies. In: Parallel and distributed processing symposium, international proceedings, vol 2, p 184; 2002.

25. Kumar S, Stecher G, Tamura K. MEGA7: molecular evolutionary genetics analysis version 7.0 for bigger datasets. Mol Biol Evol. 2016;33:1870-4.

26. Kimura M. A simple method for estimating evolutionary rate of base substitutions through comparative studies of nucleotide sequences. J Mol Evol. 1980;16:111-20.

27. Ornelas-Gatdula E, Camacho-García Y, Schrödl M, Padula V, Hooker Y, Gosliner TM, Valdés A. Molecular systematics of the'Navanax aenigmaticus' species complex (Mollusca, Cephalaspidea): coming full circle. Zool Scr. 2012;41(4):374-85.

28. Alexander J, Valdés A. The ring doesn't mean a thing: molecular data suggest a new taxonomy for two Pacific species of sea hares (Mollusca: Opisthobranchia, Aplysiidae). Pac Sci. 2013;67(2):283-94.

29. Krug PJ, Vendetti JE, Rodriguez AK, Retana JN, Hirano YM, Trowbridge $\mathrm{CD}$. Integrative species delimitation in photosynthetic sea slugs reveals twenty candidate species in three nominal taxa studied for drug discovery, plastid symbiosis or biological control. Mol Phylogenet Evol. 2013;69(3):1101-19.

30. Carmona L, Bhave V, Salunkhe R, Pola M, Gosliner TM, Cervera JL. Systematic review of Anteaeolidiella (Mollusca, Nudibranchia, Aeolidiidae) based on morphological and molecular data, with a description of three new species. Zool J Linn Soc. 2014;171:108-32.

31. Carmona L, Lei BR, Pola M, Gosliner TM, Valdés A, Cervera JL. Untangling the Spurilla neapolitana (Delle Chiaje, 1841) species complex: a review of the genus Spurilla Bergh, 1864 (Mollusca: Nudibranchia: Aeolidiidae). Zool J Linn Soc. 2014;170:132-54.

32. Goodheart J, Camacho-García Y, Padula V, Schrödl M, Cervera JL, Gosliner TM, Valdés A. Systematics and biogeography of Pleurobranchus Cuvier, 1804, sea slugs (Heterobranchia: Nudipleura: Pleurobranchidae). Zool J Linn Soc. 2015;174:322-62.

33. Churchill CK, Valdés A, Foighil DO. Afro-Eurasia and the Americas present barriers to gene flow for the cosmopolitan neustonic nudibranch Glaucus atlanticus. Mar Biol. 2014;161(4):899-910.

34. Paige JA. Biology, metamorphosis and postlarval development of Bursatella leachii plei Rang (Gastropoda: Opisthobranchia). Bull Mar Sci. 1988:42(1):65-75.

35. Clarke CL. The population dynamics and feeding preferences of Bursatella leachii (Opisthobranchia: Anaspidea) in northeast Queensland, Australia. Rec West Aust Mus Suppl. 2006;69:11-21.

36. Blackburn TM, Cassey P, Lockwood JL. The role of species traits in the establishment success of exotic birds. Glob Change Biol. 2009;15(12):2852-60.

37. Gollasch S, Lenz J, Dammer M, Andres HG. Survival of tropical ballast water organisms during a cruise from the Indian Ocean to the North Sea. J Plankton Res. 2000;22(5):pp. 923-937.33.

38. Jones PD, Parker DE, Osborn TJ, Briffa KR. Global and hemispheric temperature anomalies - land and marine instrumental records. In: Trends: a compendium of data on global change. Carbon Dioxide Information Analysis Center, Oak Ridge National Laboratory, U.S. Department of Energy, Oak Ridge. 2016. http://cdiac.ess-dive.lbl.gov/trends/temp/jones cru/jones.html. Accessed 18 May 2018.

39. Valdés A, Alexander J, Crocetta F, Yokeş MB, Giacobbe S, Poursanidis D, Zenetos A, Cervera JL, Caballer M, Galil BS, Schembri PJ. The origin and dispersal pathway of the spotted sea hare Aplysia dactylomela (Mollusca: Opisthobranchia) in the Mediterranean Sea. Aquat Invasions. 2013;8(4):427-36

40. Bianchi CN. Biodiversity issues for the forthcoming tropical Mediterranean Sea. Hydrobiologia. 2007;580(1):7-21.

41. Travaglini A, Crocetta F. Natural history collections and alien species: an overlooked sample of Bursatella leachii Blainville, 1817 (Mollusca: Gastropoda: Anaspidea) backdates its confirmed presence in Italy. Thalass Int J Mar Sci. 2018. https://doi.org/10.1007/s41208-018-0101-2. 